are developed and maintained while preserving the benefits of the new system of health care.

These challenges confront all regions in the country but are especially important in London. As hospitals in the capital are reconfigured, as services currently located in specialist hospitals which are perceived as too dispersed are relocated, and as some skilled staff take the opportunity to bow out of the service, it is essential that the present and future place of specialised services are secured within the network of care.

I am grateful to my colleagues Bill Kirkup and Tim Watkinson for the thinking which resulted in the contract matrix shown in table III. 1 Secretaries of State for Health, Wales, Northern Ireland and Scotland.
Working for patients. London: HMSO, 1989. (Cmnd 555.)

2 Report of the inquiry into London's health service, medical education and research. London: HMSO, 1992.
3 House of Commons Health Committee. Second report. Maternity services. London: HMSO, 1992. (HC 29-1.)

Royal Commission on the National Health Service. Report. London: HMSO, 1979. (Cmnd 7615.)

A hospital plan for England and Wales. London: HMSO, 1962. (Cmnd 1604 .)

6 Central Health Services Council. The functions of the district general hospital. London: HMSO, 1969.

7 Roberts H. Outcome and performance in health care: a guide to developments in outcome and performance assessment in the NHS. London: Public Finance Foundation, 1990

8 Department of Health Research and Development Division. Research for Health: a research and decelopment strategy for the NHS. London: Department of Health, 1991

9 Advisory Group on Health Technology Assessment. Assessing the effects of health technologies: principles, practice, proposals. London: Department of Health, 1992.

10 Khanna R, Richmond S. Antenatal treatment to enhance maturity. In: Repon on pernatal and late neonatal death $m$ the Northerm region 1991. Newcastle upon Tyne: Northern Regional Health Authority, 1992.

11 Liggins GC Howie RV A controlled trial of antepartum glucocorticoid treatment for prevention of the respiratery distress syndrome in prematre infane

12 Crowlev P. Promoting pulmonary maturity. In: Chalmers I, Enkin .M, Keirse MJNC, eds. Effective care in pregnancy and childbirth. Oxford: Oxford University Press, 1989:125-30.

\title{
Using a mock trial to make a difficult clinical decision
}

\author{
Richard Smith
}

The motion: Bone marrow transplantation should forthwith be offered to all children in the UK with symptomatic sickle cell anaemia who have HLA matched siblings.

British Medical Journal, London WC1H 9JR Richard Smith, editor
Many clinical decisions have to be taken with inadequate scientific information. Reaching a consensus among experts has been tried as one response to this problem. Another, described here, is to use legal process to dissect a difficult question. In this case a mock trial-using barristers, expert witnesses, and a jury-was conducted on whether bone marrow transplantation should be offered to all children with symptomatic sickle cell disease. Transplantation seems to offer about a $90 \%$ cure rate for a condition that may kill $15 \%$ of children before they reach 20 . But transplantation carries a $10 \%$ risk of death or severe disability, and doctors cannot predict which children will suffer severly from their sickle cell disease and which will suffer little or nothing. The jury eventually reached a majority decision that transplantation should not be offered now to all symptomatic children.

Haematologists cannot agree whether children with symptomatic sickle cell disease should be offered bone marrow transplantation. Preliminary evidence suggests that it may be the only "cure" for this potentially fatal condition ${ }^{12}$ : the transplanted marrow replaces the diseased marrow and the child thereafter produces normal haemoglobin. Some haematologists want to offer bone marrow transplantation to children with symptomatic disease-despite the fact that bone marrow transplantation itself may kill or disable. Others think it premature to offer the treatment so broadly and that much more evaluation needs to be done first.

Sally Davies, a haematologist from the Central Middlesex Hospital, faces the dilemma of whether to offer such treatment and recently attended a National Institutes of Health workshop on the subject. ${ }^{3}$ Consensus could not be reached. She wanted help with her dilemma and thought that she might look to legal methods. After all, the courts are daily having to sift through evidence and make judgments on what look like impossibly difficult problems; and $\mathrm{Dr}$ Davies had been impressed by how cross examination by barristers when she had appeared as an expert witness had helped her clarify her own thinking on difficult issues. Another advantage of trials is that they must be conducted in ordinary language, allowing patients and others to be brought into the debate.

Dr Davies set up a mock trial on the use of bone marrow transplantation in the Middle Temple. She managed to persuade three Queen's Counsels and four eminent haematologists, two of them from the United States, to participate in the trial. In addition, she assembled a jury of non-experts: a nurse with sickle cell disease, a mother whose child had died of the disease, a black community activist, a black barrister, a black junior doctor, a regional medical officer, and the editor of a general medical journal (me).

We had six hours to argue it out in the wood panelled hall under five gigantic pictures of kings of England. The motion was that "Bone marrow transplantation should forthwith be offered to all children in the UK with symptomatic sickle cell anaemia who have HLA matched siblings."

\section{Case for the motion}

Jean Richie QC opened her case by telling the jury and audience that some 5000 people in Britain have sickle cell disease; about $60-70 \%$ of these have the double recessive form of the disease to which the motion refers. In any given case the course is "totally unpredictable." Patients may be unaffected by the disease, or they may die of it. Cross sectional, hospital based data from the United States show that $15 \%$ of patients with double recessive disease die before they are 20 and $50 \%$ before 40 . Patients may die of infection, stroke, or organ failure, and they may suffer a wide range of problems, including vaso-occlusive crises, brain damage, impotence, and blindness.

Routine treatment includes prophylactic antibiotics and blood transfusion, but attempts to develop antisickling drugs have failed. One treatment that may prove useful is hydroxyurea, which encourages the production of fetal haemoglobin. Although this treatment is undergoing a controlled trial, the results are not yet available. Hydroxyurea is not recommended in children because of fear of long term side effects. Gene therapy may eventually be useful, but nothing is yet available. Prenatal diagnosis and termination of pregnancy is offered for double recessive disease, and uptake is about $50 \%$ in both Britain and the United States.

Bone marrow transplantation from an HLA matched donor is the only current "cure" for the condition. It has been used in some 40 patients-mostly Africans 
treated in Belgium - and the results are said to be good. A series of 12 patients was published in the Archives of Disease in Childhood: all were still alive, and 11 had accepted the graft-one after an episode of red cell hypoplasia. ${ }^{2}$ The problem with bone marrow transplantation is that about $5 \%$ of children die (from infection, bleeding, graft rejection, and acute graft versus host disease) and about another $5 \%$ suffer severe long term complications. Ms Richie argued that this $10 \%$ risk of death or severe morbidity was worth the $90 \%$ chance of being cured from a disease that kills $50 \%$ of patients before they are 40 .

\section{"Uncertainty is the most difficult thing for children with sickle cell disease and their parents."}

Her first expert witness was Professor K OheneFrempong from Philadelphia, a man who not only runs one of the 10 comprehensive sickle cell centres in the United States but also has a 20 year old son with the condition. Professor Ohene-Frempong said that "uncertainty is the most difficult thing for children with sickle cell disease and their parents." Prophylactic penicillin given from birth may reduce mortality, and many children with the disease have a high quality of life. Indeed, hospital based data may be distorted by some healthy patients never coming near hospital-but then again others may die before their disease is recognised.

Professor Ohene-Frempong said that he was concerned about the long term use of hydroxyurea in children and that the only really effective treatment currently available was bone marrow transplantation. $\mathrm{He}$ is considering recommending it in children who have had many episodes of pain and in those who have evidence of narrowing of cerebral vessels on magnetic resonance imaging. And he would have recommended it for his own son but for the fact that he is too old (the treatment is recommended only in those under 15).

Robert Francis QC, arguing against the motion, cross examined Professor Ohene-Frempong and got him to concede that many children-both in the United States and the United Kingdom-are not currently getting optimum treatment for their sickle cell disease. If they did many might live longer.

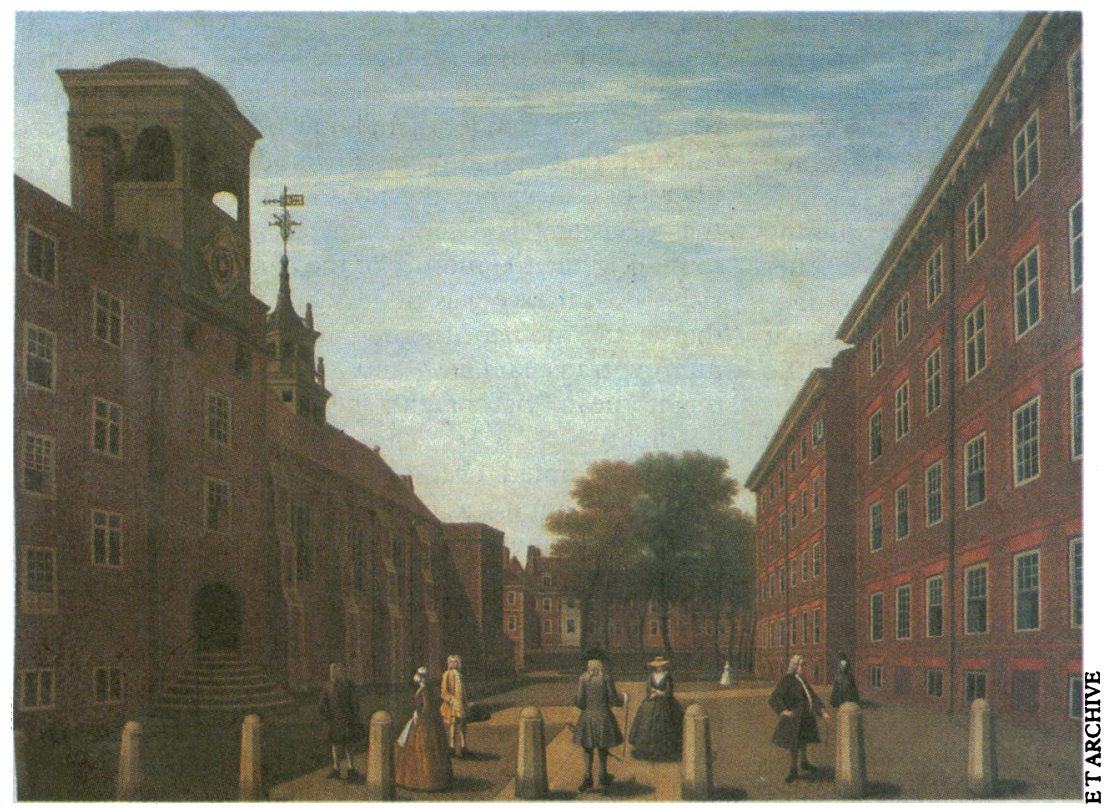

Middle Temple Hall: where medicine and law worked together
Another problem is that bone marrow transplantation is best given to children who are very young, yet it is impossible to predict which children will suffer badly from their disease and which will not suffer at all. Young children may thus be submitted to a treatment that could kill them for a condition that might never cause them any trouble. Mr Francis also elicited from Professor Ohene-Frempong that some consequences of sickle cell disease cannot be reversed by bone marrow transplantation. Next, he suggested to the professor that there was a danger that transplantation might be presented as a panacea for sickle cell disease and that resources might be diverted from the treatments that might bring benefit to the whole community (only about a fifth of patients with sickle cell disease will have an HLA compatible sibling). Professor Ohene-Frempong was not convinced by Mr Francis's arguments. Mr Francis then argued that the treatment was still experimental and that "the medical data were thin," but Professor Ohene-Frempong insisted that "we know it will work."

Ms Richie's second witness was Professor David Linch from University College Hospital; he has extensive experience of bone marrow transplantation - about 110 patients a year are treated in his department. Professor Linch said that he had no experience of transplanting the marrow of children with sickle cell disease, but his understanding was that $90 \%$ were "cured," although there were a few cases where the child had begun to produce sickle cells again. $\mathrm{He}$ emphasised that the dilemma was that through marrow transplantation "you could kill a child with only mild disease." But doctors, he said, were familiar with such dilemmas-for instance, when transplanting the marrow of adults in remission from acute myeloid leukaemia. Bone marrow transplantation has become

\section{"You could kill a child with only mild disease."}

safer in children, and he thought that there was a strong case for offering transplantation to children with symptomatic sickle cell disease. The days had gone when doctors could not mention such options to patients.

When Mr Francis cross examined Professor Linch he pressed him on how confident he could be on his predictions of cure and mortality when the data were so few and so short term: "What," he asked, "were the chances of secondary tumours, growth retardation, or impaired fertility?" "Might pressure be put on parents to consent to bone marrow transplantation?" It might, conceded Professor Linch, but he stuck to his conclusion that transplantation should be offered to all symptomatic children under 15.

\section{The case against}

Mr Francis made no opening statement but immediately called his first witness-Sir David Weatherall, regius professor of medicine at Oxford, who has long experience of treating patients with sickle cell disease and researching into the molecular biology of haemoglobinopathies. He regretted that the treament received by many children with sickle cell disease was not good: "If patients are handled by people who know what they are doing then the outlook is good." In his opinion the mortality from bone marrow transplantation was around $5 \%$ and yet the mortality from the disease itself need be only $1 \%$ for patients under 10 if they were treated well. The transplant had to be done early, when you had no idea what the outcome would be for the 
child, yet if it was done on a child who had suffered a severe complication-like a stroke-then the transplant could do little good.

Nevertheless, he thought that there was a case for doing transplants in a few centres on children with serious disease in order to learn more about the treatment. The Belgian evidence was not enough to roll out the treatment broadly, and it was much more important to improve the care of all children-in particular they should all get prophylactic penicillin. By thinking of offering bone marrow transplantation to everybody "we are trying to run before we can walk." Another problem was that we don't know much about the clinical course of sickle cell disease in the community; most data are based on hospital practice, and the disease overall may be much milder than we realise.

Cross examining Sir David, Ms Richie said that he seemed to agree that some symptomatic children should be offered transplantation and that therefore the argument was over who it should be offered to, not whether it should be offered. Sir David replied that he thought that the categories were so limited that the number of patients falling into them was almost none. He emphasised again how little we know about the effectiveness of transplantation and the clinical course of the disease. Ms Richie pointed out that many doctors had been against offering transplants to children with $\beta$ thalassaemia and yet that was now

\section{"The red cells may be fixed but not the child."}

almost routine. Sir David said that he still wasn't convinced of the benefit of that treatment-all the quoted data come from one Italian centre-and he didn't think that you could say that what might be good for children with $\beta$ thalassaemia would necessarily be good for children with sickle cell disease.

The next witness was Professor $S$ Charache from Johns Hopkins Hospital, who Mr Francis introduced as "a father of sickle cell disease." $\mathrm{He}$ is leading the research on the use of hydoxyurea in the disease and confirmed that it is not yet proved to be clinically efficacious. A controlled trial is being conducted, but one of the big problems, said Professor Charache, is getting a "rigid, rugged definition of severity - and if we don't we can't measure it. The trouble is that it is the psychosocial implications of the disease that handicap people. Fixing up the red cells may not do the job. The red cells may be fixed but not the child." $\mathrm{He}$ was worried that these problems in defining severity would mean that it was difficult to decide which children ought to be offered a transplant. Nevertheless, he thought that there might be a case for offering transplantation to a child with a stroke. For most other complications (lung disease, kidney failure, retinovascular lesions, and bone disease) he thought that it was unclear what the prognosis of the child would be either with or without a transplant. He thought that doctors should not offer treatment to patients when they had no idea themselves what was the best treatment. Finally, he argued that if you had only limited resources you would do better to improve care in the community for all children with sickle cell disease rather than give transplants to some children with severe disease who happened to have an HLA compatible sibling.

Ms Richie again pursued the line that the argument was not about whether symptomatic children should be offered transplantation but which. Professor Charache was unimpressed.

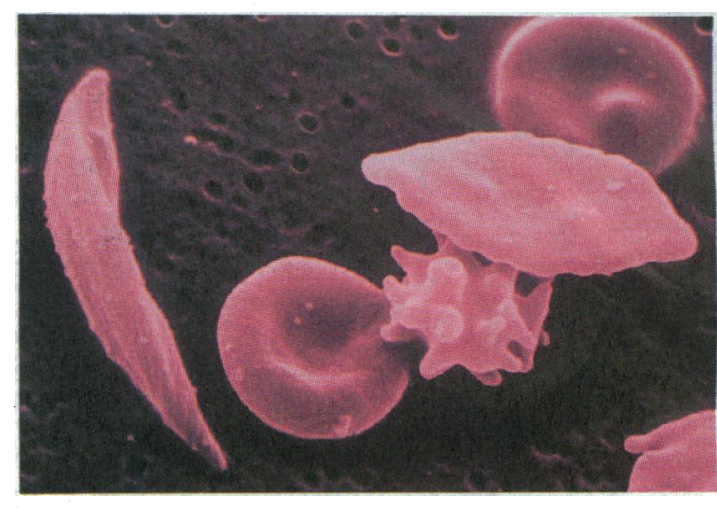

The sickle cell: guilty of killing $15 \%$ of affected patients before 20

\section{Summing up}

In summing up $\mathrm{Mr}$ Francis brought out the arguments that doctors have only poor information about both sickle cell disease and bone marrow transplantation, that a treatment with a $10 \%$ chance of death or severe handicap would have to be offered to children without any way of telling what their prognosis would be, and that with limited resources it would be better to spend them on improving community care. Nevertheless, his side was not against the experimental use of bone marrow transplantation, and he suggested to the jury that it might turn down the motion but suggest another one that allowed for the use of the treatment in experimental circumstances.

Ms Richie said that bone marrow transplantation offered the only cure for this dreadful condition and that the risks of the treatment were therefore worth taking. Furthermore, she asked, "Don't patients have the right to know about the options?"

Adrian Whitfield QC, acting as judge, summed up the arguments for the jury and reminded it that there are around 5000 patients with all types of sickle cell disease in Britain, about 2000 of whom are under 15 and have the double recessive form of the disease - and about 400 of whom could expect to have an HLA compatible sibling.

\section{The decision}

The jury couldn't agree. The nurse, the barrister, the regional medical officer, and the editor all thought that the data on the effectiveness of bone marrow transplantation and the clinical course of sickle cell disease were too sparse to make it sensible to offer the treatment to all symptomatic children forthwith. The community activist thought that patients and their parents had to be offered the treatment and that it was wrong not to even let them know of the treatment: she thought that often parents would not take up the offer-but they, not the doctors alone, had to make that decision. The junior doctor also supported the motion, while the mother of the child who had died of sickle cell disease was undecided. She was concerned that at the moment there is no cure apart from bone marrow transplantation and that rejecting the motion might mean that parents never got to hear of the possibility.

We attempted over about half an hour to reach agreement, but it was clear that we would have needed much more time either to agree on what we thought about the motion or to draft another one. The motion was thus lost by a majority decision.

\section{A better way to settle uncertainty?}

More is uncertain than certain in medicine. The quality of scientific evidence underlying what we do is poor ${ }^{45}$ and a worldwide effort is underway to identify 
what we know and what we don't know, to devise research programmes to learn more about what we don't know, and to decide on actions that doctors should take in the meantime. ${ }^{6}$ Guidance from a respected clinical leader has been the traditional way to decide on what to do, but this has increasingly given way to consensus statements and guidelines drawn up by groups. Sometimes, however, doctors may not agree, even though they appear to, and the quality of consensus statements may be poor.

The mock trial with leading experts being cross examined by barristers is an alternative way to try to reach a conclusion on what clinical actions to take when scientific evidence is inadequate. The skilled cross examination may dissect out disagreements that are not confronted in consensus conferences and clarify thinking. A particular advantage is that the argument must be conducted in language that everybody can understand, meaning that non-experts, including lay people, can take part in deciding the best course of action. Indeed, a lay jury - in the true legal traditionmight make the decision.

But the method also has its problems. Firstly, the debate may be constricted by the need to build it around a particular motion. In this case the jury might have been able to agree over another motion, but putting together an alternative motion in a jury room is formidably difficult. Secondly, the adversarial nature of the debate may dissect out particular issues clearly but neglect broader subjects. In this case the material on cost effectiveness was inadequate. Thirdly, the fact that the jury and audience cannot ask questions and that the experts cannot question each other feels artificial and surely restricts understanding. Fourthly, a jury might need a huge amount of time to reach a real verdict: I think we would have needed all night to agree. Finally, I question whether the doctors who offer the treatment will be influenced by the jury's decision. Many of the haematologists and paediatricians in the audience seemed more enthusiastic about bone marrow transplantation than the jury turned out to be, and I wonder if their thinking has been much altered.

But even if mock trials do not take over from consensus conferences they are a powerful way of bringing out the arguments. And they are fun. I predict that there will be more.

The conference was sponsored by Amgen, Centocor, Cilag, Glaxo, Farmitalia Carlo Erba, Lederle, and Vestar.

1 Vermlyn C, Fernadez Roble E, Ninane J, Cornu G. Bone marrow transplantation in five children with sickle cell anaemia. Lancet 1988;i:1427-8.

2 Vermlyn C, Cornu G, Philippe M, Ninane J, Borja A, Latinne D, et al. Bone marrow transplantation in sickle cell anaemia. Arch Dis Child 1991;66: $1195-8$.

3 Davies SC. Report on the NIH workshop, June 1992. Sickle Cell Society Newsletter (in press).

4 Smith R. Where is the wisdom ...? BMf 1991;303:798-9.

5 Smith R. The ethics of ignorance. $\mathcal{F}$ Med Ethics 1992;18:117-8

6 Chalmers I. Getting to grips with Archie Cochrane's agenda. BMf 1992;305: 786-8

\section{OBITUARY}

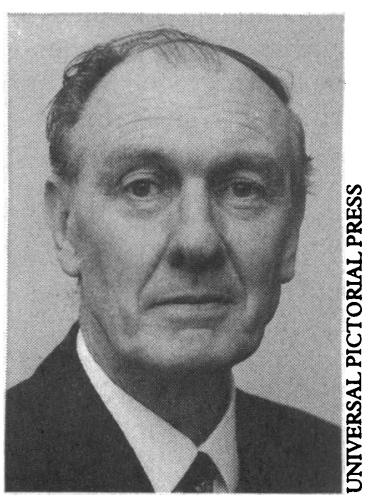

$A W W o o d r u f f$

\section{A W WOODRUFF}

CMG, OBE, PHD, MD, FRCP, FRCPED, DTM\&H

After war service that took him to India and Burma Alan Woodruff devoted his professional life to tropical medicine, becoming one of the leading authorities in this specialty. In Britain he became well known for his work on toxocariasis, drawing attention to the widespread distribution of toxocara eggs in the environment and developing tests to aid diagnosis. With his support and encouragement de Savigny and Voller in his department developed the enzyme linked immunosorbent assay for serological diagnosis of toxocariasis; this remains the most commonly used serological test. He attracted criticism from those who thought his recommendations to reduce the chances of transmission "anti-dog," but his concern was to prevent a transmissible disease. He was also interested in anaemia caused by malaria and nutritional disorders and in tropical sprue. He carried out field studies on onchocerciasis in west Africa and central America

His reputation was recognised by awards from the BMA, the Royal College of Physicians of Edinburgh, and the University of Pernambuco in Brazil. Goulstonian (1954) and Watson-Smith (1970) lecturer of the Royal College of Physicians of London, he also gave the Lettsomian lecture of the Medical Society of London (1969), and the Halliburton-Hume lecture of the University of Newcastle upon Tyne (1981). He held the presidency of the Royal Society of Tropical Medicince and Hygiene in 1973-5, having previously been honorary secretary, and the presidency of the Medical Society of London in 1975-6. He was also a member of several committees of the World Health Organisation and the Medical Research Council.

After his retirement in 1981 he went to the University of Juba in Sudan to help start clinical teaching in the faculty of medicine there. His aim was to see the first group of clinical students through to qualification.
Last summer saw the end of his last contract with the university; during the intervening years the university had been closed for varying periods due to unrest and civil war, and eventually the staff and students had to move to Khartoum because of the danger. At the time of his death he had returned to Khartoum to lecture.

History and art were his particular interests outside medicine. He wrote on the nature of Darwin's illness, countering the view that Darwin might have acquired Chagas's disease during his visit to South America, and served as president of the historical section of the Royal Society of Medicine. He was a talented wood engraver and used his work to decorate his Christmas cards. A sociable man and welcoming host, he is survived by his wife, Helen, and his daughter and two sons, one of whom is a physician.- $S \mathrm{G}$ WRIGHT

Alan Waller Woodruff, professor of medicine at the University of Juba in Sudan 1981-92 and, before that, Wellcome professor of clinical tropical medicine at the London School of Hygiene and Tropical Medicine and physician at the Hospital for Tropical Diseases 1952-81, died 12 October. Born 27 fune 1916; educated Bede Collegiate School, Sunderland, and Durham University (MB, BS 1939). Served in Royal Air Force Volunteer Reserve 1940-6. Medical registrar at Royal Victoria Infirmary, Newcastle upon Tyne, 1946-8. Senior lecturer in clinical tropical medicine at London School of Hygiene and Tropical Medicine 1948-52. Appointed CMG 1978 and OBE 1989.

\section{$R$ W D TURNER}

OBE, MD, FRCP, FRCPED

Beware of the cow! This might have been Dick Turner's chosen epitaph for his stone in Ditchling churchyard. The last 20 years of his life were devoted to a singleminded campaign against the British beef and dairy industry and its sponsors in the government and European Community. At the funeral we sang Bunyan's lines "There's no discouragement shall make him once relent. ..." Like Bunyan, Dick had uncomfortable things to say and was viewed in some and good quality, recent photographs, and, as a medical journal, we encourage authors to include the cause of death. 